\title{
GAPDH Gene
}

National Cancer Institute

\section{Source}

National Cancer Institute. GAPDH Gene. NCI Thesaurus. Code C104409.

This gene is involved in carbohydrate metabolism. 